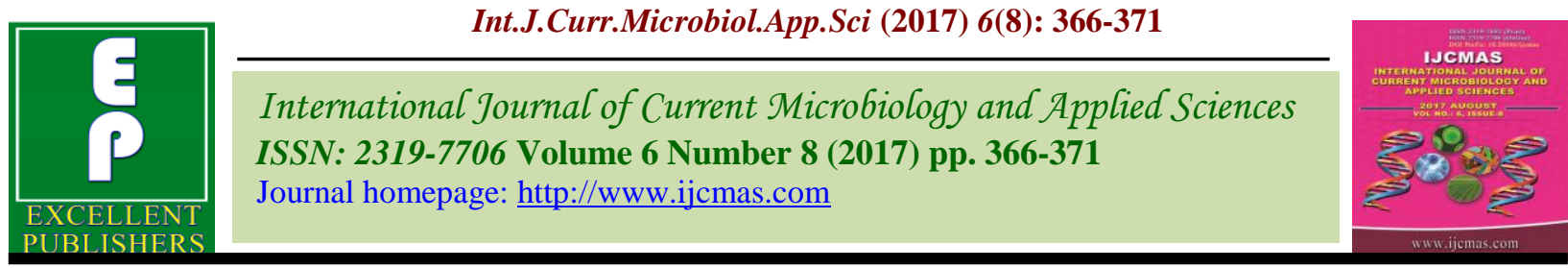

Original Research Article https://doi.org/10.20546/ijcmas.2017.608.049

\title{
Sero Biochemical Profile of Crossbred Calves Naturally Infected By Bovine Papilloma Virus
}

\author{
K.M. Palanivel, A.P. Surendar* and P. Kanimozhi \\ Department of Veterinary Epidemiology and Preventive Medicine, Veterinary College and \\ Research Institute, Namakkal, Tamil Nadu Veterinary and Animal Sciences University, \\ Tamilnadu, Chennai, India \\ *Corresponding author
}

\section{A B S T R A C T}

\section{Keywords}

Bovine fibro papillomatosis, Histopathology, Hematology, Serobiochemical values and crossbred calves.

Article Info

Accepted:

04 June 2017

Available Online:

10 August 2017
Bovine fibropapillomatosis has been reported previously by various authors in India, but the sero biochemical profile of the disease has not been described so far in Tamil Nadu, elsewhere in India. The present study is on hematological, sero biochemical and histopathological changes in eight naturally infected calves were compared with eight healthy calves. In appetence, localised skin warts in the lips, upper eyelids, lower jaws almost entire head and neck region followed by intermittent scratching were noticed in calves which revealed a significant reduction $(\mathrm{p}<0.001)$ in Total Erythrocyte Count (TEC), Haemoglobin Concentration (Hb), Packed Cell Volume (PCV), Total Leukocyte Count (TLC), neutrophils, lymphocytes, total proteins, sodium and potassium. The biochemical values from affected calves had significantly $(\mathrm{p}<0.001)$ higher values of Alanine aminotransferase (ALT) $\left(16.5 \pm 0.60 \mathrm{IUL}^{-1}\right)$, Aspartate aminotransferase (AST) $\left(181.1 \pm 3.10 \mathrm{IUL}^{-1}\right)$, Gamma glut amyl transferase (GGT) $\left(33.2 \pm 2.40 \mathrm{IUL}^{-1}\right)$ and Alkaline phosphatase (ALP) $\left(107.2 \pm 2.40 \mathrm{IUL}^{-1}\right)$ in comparison with healthy calves $(13.4$ $\pm 2.10,132.0 \pm 4.00,20.4 \pm 2.30$ and $\left.42.2 \pm 1.90 \mathrm{IUL}^{-1}\right)$ respectively. However, affected calves had significantly $(\mathrm{p}<0.001)$ lower values of total protein $\left(4.2 \pm 0.04 \mathrm{gdL}^{-1}\right)$, sodium $\left(100.5 \pm 7.10 \mathrm{~m} \mathrm{EgL}^{-1}\right)$ and potassium $\left(5.2 \pm 0.62 \mathrm{~m} \mathrm{Eg} \mathrm{L}^{-1}\right)$, when compared to healthy calves $\left(7.6 \pm 1.44 \mathrm{gdL}^{-1}, 126.0 \pm 7.10\right.$ and $\left.8.1 \pm 0.81 \mathrm{~m} \mathrm{EgL}^{-1}\right)$ respectively. The cutaneous papilloma wart specimens revealed finger like projection of papillary proliferation by histopathologically. In the present study bovine fibro papillomatosis occurs in crossbred calves in this region were reported.

\section{Introduction}

Papillomatosis or cutaneous wart is a disease occurring in cattle, goats, rabbits and horses affecting any part of the body (Radostits et al., 2007), assuming the appearance of cauliflower like growth. Bovine papillomatosis is a contagious disease of cattle occurring as warts/papillomas on skin and mucosa caused by bovine papillomas virus (BPV) types 1 to 10 (Vidya et al.,
2009). Papillomas viruses (PVs) are classified in the family papilloma viridae. This family of animal and human PVs generally infects epithelial cells causing hyper proliferative lesions known as wart (Singh and Somvanshi, 2010).

Several authors have reported the papillomatosis in goats, sheep and cattle 
(Makady et al., 1990; Uzal et al., 2000). This study describes the biochemical and clinicopathological changes and detection of BPVs in crossbred calves in Tamil Nadu, India.

\section{Materials and Methods}

One hundred and seventy adult dairy cows and thirty five female calves aged about 6-9 month old were maintained at Livestock Research Station, Kattupakkam, Tamil Nadu, South-West region of India. The animals were maintained in semi-intensive system of management and provided with $\mathrm{Co}-3$ and Co4 grasses and concentrate (16\% crude protein) feed with ad libidum supply of water. Eight of the thirty five female calves suffering from cutaneous bovine papillomatosis.

Blood samples were collected once in 3 days by jugular venipunture from the healthy and affected calves for haematological and serum biochemical analysis for forty five (45) days. For haematological parameters, the blood samples were collected in vacutainer ${ }^{\mathrm{TM}}$ tubes, with and without anticoagulant EDTA for determination of $\mathrm{Hb}$ concentration, PCV, TEC and TLC and biochemical parameters. Red and white blood cells were counted by using hematocitometer. Blood smears were prepared for determining the differential counts of white blood cells by Wrights stain. The TEC, Hb concentration and PCV were determined by following method described by Ferver (1997). For biochemical parameters, sera were separated by centrifugation and stored at $-20^{\circ} \mathrm{C}$ till time of analysis. The sera were analysed for determination of concentration of serum proteins, creatinine, Blood Urea Nitrogen concentration (BUN), sodium, potassium and the level of serum AST, ALT, ALP and GGT.

Commercial diagnostic kits (Span diagnostic Ltd, Gujarat, India) were used for assessing the value of Glucose (LS 77L-200), total proteins (LS56-200), Albumin (LS84-100), ALT (LS76-200), AST (LS77-200), ALP (LS03-200), BUN (LS20-200), Creatinine (LS33K-200), Cholesterol (LS24-200), Calcium (LS22-*200), Magnesium (LS83200) on colorimetric technique. Concentration of the biochemical constituents were calculated according to the manufacture instruction. GGT was determined by spectrophotometrically using commercially available kits (Ranbaxy Laboratory Ltd). Sodium and potassium were determined by flame photometric method as described by Tennant et al., (1972).

The crossbred calves were closely monitored twice daily up to 45 days for any clinical abnormalities. Pulse rate was recorded twice a day from coccygeal artery. Rectal temperature and respiration rates were recorded twice a day. Skin warts or/ papilloma were resected under aseptic condition and fixed in $10 \%$ neutral formalin, sent to Central University Laboratory, TANUVAS, Chennai, mounted in paraffin, sectioned and stained with hematoxylin eosin as per the standard histopathological procedures.

Data were analysed as per the method described by Snedecor and Cochran (1994). Means \pm standard errors were calculated and tested for significance between groups using the ' $t$ ' test.

\section{Results and Discussion}

Bovine papillomatosis has been reported in different parts of the world. However, its clinicopathological changes are not available in cattle. The onset of epidemic of wart started as small (single) eruption on the face at the upper and lower lips particularly muzzle area, latter on numerous nodules elevated in large pedunculated nodules. The lesions were first appeared as smooth and 
within 12-15 days invariably it become rough and horny in the form of cauliflower like nodules, appeared in all the eight calves and separated from the healthy susceptible herd mates in the calf shed (Fig. 1).

The affected heifer calves were intermittently rubbed their affected area over the wall. There is no adverse change in body temperature, respiratory and pulse rates in affected calves and showed in appetence. The condition was diagnosed as BPV type 2 and confirmed as positive for benign form according to the typical clinical picture of the disease and histopathological changes.

In the present study the observed haematological values were depicted in table 1. The affected calves revealed a drastic reduction in $\mathrm{Hb}$ concentration, $\mathrm{PCV}$, TEC, TLC, neutrophils and lymphocytes values.

The recorded data depicted in table 2 indicates that affected crossbred calves had significantly $(\mathrm{P}<0.001)$ higher values of ALT. Histopathological examination of cutaneous warts revealed multiple papillary proliferations covered with zone of finger like projections (Fig. 2).

The clinical sign, microscopic changes and gross lesions observed in the present study is well corroborated with the earlier reported data (Khalafala, 1998; Valentine, 2004; Ure 2011). Most of the cutaneous wart nodules caused by BPV- type 1 and 2 and confirmed to be positive for benign type by number of research workers (Bam et al., 2012; Pangry et al., 2010; Turk et al., 2005; Smith, 1990). A drastic reduction in TEC, $\mathrm{Hb}$ concentration and PCV was recorded in the diseased calves. The development of leucopenia due to neutropenia and lymphopenia suggests that the disease had an action for formation of the circulating leucocytes and/ or it might be attributed to release of endogenous corticosteroids in response to stress (Gwazdauskas et al., 1982).

Table.1 Hematological profile of diseased and healthy crossbred calves affected by papilloma virus $(\mathrm{n}=8)$

\begin{tabular}{|l|c|c|}
\hline \multirow{2}{*}{ Parameters } & \multicolumn{2}{|c|}{ Observed values } \\
\cline { 2 - 3 } & Healthy calves & Diseased calves \\
\hline TEC $\left(10^{12} / \mathrm{MM}^{3}\right.$ & $9.60 \pm 0.50$ & $6.80 \pm 0.76^{*}$ \\
\hline Hemoglobin $\left(\mathrm{gdL}^{-1}\right)$ & $15.00 \pm .02$ & $10.1 \pm 0.13^{*}$ \\
\hline Packed cell volume & $29.30 \pm 0.24$ & $23.6 \pm 0.11^{*}$ \\
\hline TLC $\left(10^{3} / \mathrm{MM}^{3}\right)$ & $10.90 \pm 0.61$ & $8.2 \pm 2.0^{*}$ \\
\hline Neutrophils $\left(10^{3} / \mathrm{mm}^{3}\right)$ & $4.67 \pm 0.21$ & $3.0 \pm 0.02^{*}$ \\
\hline Lymphocytes $\left(10^{3} / \mathrm{mm}^{3}\right)$ & $6.10 \pm 0.14$ & $4.7 \pm 0.20$ \\
\hline Monocytes $\left(10^{3} / \mathrm{mm}^{3}\right)$ & $0.20 \pm 0.04$ & $0.2 \pm 0.03$ \\
\hline Eosinophils $\left(10^{3} / \mathrm{mm}^{3}\right)$ & $0.23 \pm 0.00$ & $0.2 \pm 0.04$ \\
\hline Basophils $\left(10^{3} / \mathrm{mm}^{3}\right)$ & $0.17 \pm 0.02$ & $0.2 \pm 0.03$ \\
\hline
\end{tabular}

Mean \pm SER, $*(\mathrm{P}<0.001)$ Significant difference between healthy crossbred calves. 
Table.2 SERO biochemical Profile in diseased and health crossbred calves affected by Papilloma virus $(n=8)$

\begin{tabular}{|c|c|c|}
\hline \multirow[t]{2}{*}{ Parameters } & \multicolumn{2}{|c|}{ Observed values } \\
\hline & Healthy calves & Diseased calves \\
\hline Total protein $\left(\mathrm{gdL}^{-1}\right)$ & $7.6 \pm 1.44$ & $4.2 \pm 0.04 *$ \\
\hline Albumin $\left(\mathrm{gdL}^{-1}\right)$ & $4.8 \pm 0.60$ & $2.2 \pm 0.03$ \\
\hline Globulin $\left(\mathrm{gdL}^{-1}\right)$ & $2.8 \pm 0.84$ & $2.0 \pm 0.01$ \\
\hline Glucose $\left(\mathrm{mgdL}^{-1}\right)$ & $110.0 \pm 4.23$ & $115.2 \pm 3.60$ \\
\hline Cholesterol $\left(\mathrm{mgdL}^{-1}\right)$ & $32.0 \pm 2.40$ & $30.2 \pm 0.60$ \\
\hline ALT $\left(\right.$ IUL- $\left.^{-1}\right)$ & $13.4 \pm 2.10$ & $16.5 \pm 0.60^{*}$ \\
\hline AST $\left(\right.$ IUL- $\left.^{1}\right)$ & $132.0 \pm 4.00$ & $181.1 \pm 3.10^{*}$ \\
\hline $\operatorname{ALP}\left(\right.$ IUL- $\left.^{1}\right)$ & $42.2 \pm 1.90$ & $107.2 \pm 2.40 *$ \\
\hline GGT (IUL-1) & $20.4 \pm 2.30$ & $33.2 \pm 2.40^{*}$ \\
\hline Urea $\left(\mathrm{mgdL}^{-1}\right)$ & $9.8 \pm 1.06$ & $11.2 \pm 2.10$ \\
\hline Creatinine $\left(\mathrm{mgdL}^{-1}\right)$ & $1.8 \pm 0.10$ & $2.0 \pm 0.02$ \\
\hline Potassium $\left(\mathrm{M} \mathrm{EgL}^{-1}\right)$ & $8.1 \pm 0.81$ & $5.2 \pm 0.62 *$ \\
\hline Sodium $\left(\mathrm{M} \mathrm{EgL}^{-1}\right)$ & $126.0 \pm 7.10$ & $100.5 \pm 7.10 *$ \\
\hline Calcium $\left(\mathrm{mgdL}^{-1}\right)$ & $8.2 \pm 2.00$ & $8.0 \pm 0.10$ \\
\hline Magnesium $\left(\mathrm{mgdL}^{-1}\right)$ & $3.6 \pm 1.03$ & $2.8 \pm 0.50$ \\
\hline
\end{tabular}

Mean $\pm \mathrm{SER}, *(\mathrm{P}<0.001)$ Significant difference between healthy crossbred calves.

Fig.1 Showing multiple cutaneous warts in a crossbred heifer disseminated on the head measuring from 0.5 to $50 \mathrm{~mm}$

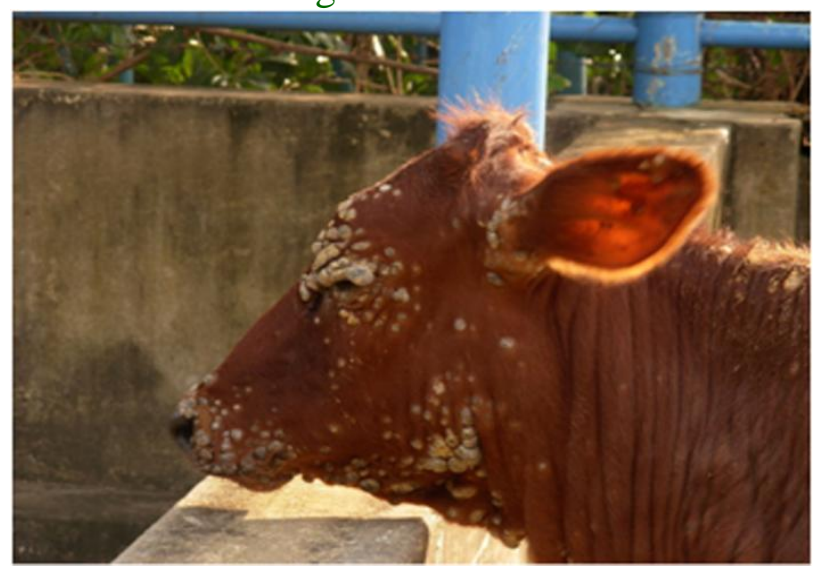

Fig.2 Showing finger like projection of papillary proliferations of a wart tissue stained with HEX100

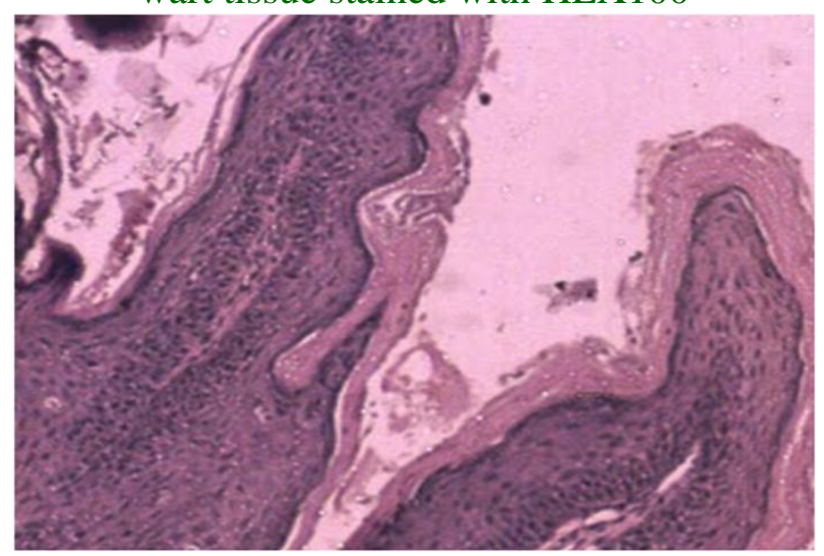


Para Pe et al., (1973) reported that AST and ALT are important and critical enzymes are involved in breakdown of amino acids in to keto acid which are routed for complete metabolism through the Kreb's cycle and electron transport chain. Consequently these enzymes considered as a specific indicator for hepatic dysfunction and damage (Shakoori et al., 1994). The levels of AST and ALT were increased in plasma due to the leakage of these enzymes from the liver cytosol in to the blood stream which indicates liver damage and dysfunction of normal liver function (Wernery et al., 1999). In the present study revealed that bovine papilloma virus could induce significant elevations of serum ALT, AST, ALP and GGT. However, there is no previous reported data that the range of reference values of these enzymes varies in bovines. Factors such as age, sex, breed, health care, fitness, feeding habit and geographic location and test procedures may contribute to the wide variations in the levels of serum enzymes in animals (Beaunoyer, 1992; Kataria et al., 2007).

The observed hypoprotenimia levels in the affected crossbred calves might be predisposed to undernourishment during the course of the disease. There is no changes could be observed in the values of urea and creatinine.

\section{Acknowledgment}

The authors are profoundly grateful to the Director, Centre for Animal Health Studies and Director, Centre for Animal Production Studies, TANUVAS, Tamilnadu, Chennai, India for provided all necessary facilities to carry out this research work.

\section{References}

Bam J, Kumar P, Leishangthem GD, Saikia A and Somvanshi R. Spontaneous cutaneous papillomatosis in Yaks and. detection and quantification of bovine papilloma virus-1 and 2. Transbounary and Emerging diseases 2012; 1-6.

Beaunoyer DE. Changes in serum enzyme activities after maximal exercise in camels. Proceedings of $I^{\text {st }}$ International camel conference, Feb, 2-6, Dubai, UAE, 1992; p. 331-33.

Ferver BT. Clinical biochemistry of domestic animals, $5^{\text {th }}$ Ed. New York, Academic Press, Inc., 1997.

Gwazdauskas FC, Paape M J, Peery D A and. McGilliard M L. Plasma glucocorticoid and circulating blood leukocyte responses in cattle after sequential intramuscular injection of ACTH. Am. J. Vet. Res., 1980; 41: 1052-56.

Kataria N, Kataria AK, Agrawal VK, Garg SL and Sahni MS.. Solute load and transfer function of kidney in dromedary camel during dehydration and rehydration in winter and summer. Vet. Arch., 2007; 77: 237-46.

Khalafala A I. Epizootiology of camel pox, camel contagious ecthyma and camel papillomatosis in the sudan. Proceedings of the International meeting on camel production and future perspective, May 2 to 3 1998. AI. Ain. UAE. 1998; Pp. 115-31.

Makady FM, Mohmoud AZ, Youssef HA and Saleh NH. Some observation on goat tumors, 1. Cutaneous tumors on the udder, 2. Vaginal cystic fibroadenoma. Assiut Vet. Med. J., 1990; 23: 213-18.

Pangry K, Singh S, Goswami R, Saikumar G and Somvanshi R. Detection of BPV-1 \& 2 and quantification of BPV-1 by real time PCR in cutaneous warts in cattle and buffaloes. Transbound. Emer. Dis., 2010; 57:185-96.

ParaPe MJ, Schultze WD and Miller RH. Thermal stress, circulating erythrocytes, leukocytes and milk 
somatic cells. J. Dairy Sci., 1973; 56: 84-91.

Radostits OM, Gay CC, Hincheliff KW and Constable P D. Veterinary Medicine. A text book of the diseases of cattle, horses, sheep, pigs and goats. Saunders Elsevier, New York, USA; 2007. P. 1421-23.

Salib FA and Fargali HA. Clinical, epidemiological and therapeutic studies on bovine papillomatosis in Northern Oases, Egypt in 2008. Vet. World, 2011; 2: 53-59.

Shakoori AR, Butt U, Riffat R and Aziz F. Hematological and biochemical effects of danitol administered for two months on the blood and liver of rabbits. Zeitschrift Fuer Ange wandte Zoologie 1994; 80: 165-180.

Singh V and Somvanshi R. BPV-2 associated papillomatosis in Indian water buffaloes. Indian J. Anim. Sci., 2010; 80: 956-60.

Snedecor C W and Cochran W G. 1994. Statistical methods, $8^{\text {th }}$ ed. East-West Press, Pvt, Ltd, New Delhi.

Smith BP. Papillomatosis (warts, fibropapillomas) In: Large Animal Internal Medicine. The C.V. Mosby Company, Missouri. 1990.

Tennant BD, Harrold and Reina-Guerra M. Physiologic and metabolic factors in the pathogenesis of neonatal enteric infections in calves. J. Am. Med. Assoc., 1972; 161: 993-07.

Turk N, Zupancic Z, Staresina VS, Kova, Babic TM, Kiesinger, Curie S, Barbic Land Milas Z. Severe bovine papillomatosis: detection of bovine papillomavirus in tumour tissue and efficacy of treatment using autogenous vaccine and parammunity inducer. Veterinarski Arhiv., 2005; 75: 391-97.

Ure AE, Alfadil AK, Khalafala AI, Gameel $\mathrm{AA}$, Dillner $\mathrm{J}$ and Forslund $\mathrm{O}$. Characterization of the complete genomes of camelus dromedavirus papilloma virus types 1 and 2. J.Gen. Virol., 2011; 92:1769-77.

Uzal FA, Latorraca AM, Ghoddusi M, Horn M, Admason M, Kelly WR and Schenkel R. An apparent outbreak of cutaneous papillomatosis in marino sheep in Patagonia, Argentina. Vet. Res. Commun., 2000; 24: 197-02.

Valentine BA. Neoplasia. In: Fubini, S.L. and N.G. Duchama, editors, Saunders, St. Louis, Missouri. 2004.

Vidya S, Somvanshi R and Tiwari K. Papillomatosis in Indian cattle: occurrence and etiopathology. Indian J. Vet. Pathol., 2009; 33: 52-57.

Wernery U, Flower ME and Wernery R. Color Atlas of Clinical Hematological and Biochemistry, Blackwell Wissenschaffs-Verlag, Berlin. 1999.

\section{How to cite this article:}

Palanivel, K.M., A.P. Surendar and Kanimozhi, P. 2017. Sero Biochemical Profile of Crossbred Calves Naturally Infected By Bovine Papilloma Virus. Int.J.Curr.Microbiol.App.Sci. 6(8): 366-371. doi: https://doi.org/10.20546/ijcmas.2017.608.049 